\title{
Profile of oral manifestations, oral hygiene, and nutritional status in pregnant women
}

\author{
Wahyu Hidayat ${ }^{1 *}$, Indra Mustika Setia Pribadi², Dewi Zakiawati ${ }^{1}$, Anne Agustina \\ Suwargiani ${ }^{3}$ \\ 1Department of Oral Medicine, Faculty of Dentistry Universitas Padjadjaran, Indonesia \\ 2Department of Periodontics, Faculty of Dentistry Universitas Padjadjaran, Indonesia \\ ${ }^{3}$ Department of Dental Public Health, Faculty of Dentistry Universitas Padjadjaran, Indonesia
}

\begin{abstract}
Introduction: The pregnancy condition leads to few changes in women's bodies, such as hormonal, physiological, and diet. These changes also manifest in dental and oral health. Hormonal changes affect the susceptibility of oral mucosal tissue, whereas emotional and dietary changes alter the pattern of dietary intake, dental cleaning, oral hygiene, and nutritional status. The purpose of this study was to discover the profile of oral manifestations, oral hygiene, and nutritional status in pregnant women. Methods: The population of the study was the pregnant women who visited the Garuda Community Health Centre in Bandung. Subjects were pregnant women aged 17-43 years old. The samples must meet the inclusion criteria of good health status, and the exclusion criteria were no systemic abnormalities, and not currently under long-term antibiotic therapy. The research design was a cross-sectional observation. Indicators measured in this survey were the profiles of oral manifestations, oral hygiene status which assessed using $\mathrm{OHI}-\mathrm{S}$, and nutritional status of pregnant women using haemoglobin $(\mathrm{Hb})$ and Body Mass Index (BMI) level. Results: Oral manifestations found in pregnant women were tongue disorders and ulceration, with the coated tongue as the most frequently detected manifestation, and the least found was recurrent aphthous stomatitis, whereas the oral hygiene of pregnant women was categorised as good in the 1st and 2nd-trimester of pregnancy. However, it was found to be moderate in the 3rd trimester. In respect of the $\mathrm{Hb}$ level, the nutritional status of the pregnant women was averagely good. By contrast, the BMI score revealed that pregnant women was found of having overweight during the 2nd and 3rd trimester. Conclusion: The most frequently found oral manifestation in pregnant women is coated tongue, while the oral hygiene is categorised as good on the first two trimesters, and the nutritional status in the last two trimesters is considered as overweight.
\end{abstract}

Keywords: Oral manifestation, oral hygiene, nutritional status.

p-ISSN: 1979-0201; e-ISSN: 2549-6212; Available from: http://jurnal.unpad.ac.id/pjd/article/view/23792 DOI: 10.24198/pjd.vol31no3.23792

Submission: Jul 13, 2019; Accepted: Nov 20, 2019; Published online: Nov 30, 2019

"Corresponding author: Wahyu Hidayat, Department of Oral Medicine, Faculty of Dentistry Universitas Padjadjaran, Indonesia. Sekeloa Selatan No. I Bandung, Indonesia, 40132. Phone: +6287822404343; Email: wahyu.hidayat@fkg.unpad. ac.id 


\section{INTRODUCTION}

The International Federation of Gynecology and Obstetrics (FIGO) explains that pregnancy is that part of the process that commences with the implantation of the conceptus in a woman, and ends with either the birth of an infant or an abortion. ${ }^{1}$ Pregnancy causes physiological changes in the body, including the oral cavity. The symptoms are primarily seen in the gingiva. Changes occur and influence the hormonal and vascular system that coincide with local irritation factors in the oral cavity. ${ }^{1}$

Pregnancy is not a predisposing factor of caries. However, the exhaustion experienced by pregnant women during the first trimester may cause negligent and inattentive behaviour in keeping dental and oral hygiene, which resulted in poor oral hygiene. Besides, high sugar consumption during pregnancy is a risk factor in increasing caries in pregnant women. ${ }^{2}$ The situation of pregnant women who often feel nauseous and vomiting causes them to be more picky in selecting the food. This manner may impact the nutritional status of pregnant women; thus, malnutrition often occurs during pregnancy.

Furthermore, there is a cumulative impact on the nutritional status of the conceived fetus. Currently, one in ten births in Indonesia experienced low birth weight (LBW). It means that there are still many pregnant women who have not paid attention to their nutritional status. Nutritional status in pregnant women can be measured through the body mass index (BMI), weight gain during pregnancy, and the haemoglobin $(\mathrm{Hb})$ level. The increase of estrogen and progesterone affects the oral mucosa. The higher the level of both hormones, the more susceptible oral mucosa towards infection and an oral lesion. The symptom happens because the function of the estrogen hormone promotes cellular proliferation and reduces cellular keratinisation.

The progesterone hormone causes blood vessel dilation. Capillary permeability inhibits collagen and non-collagen formation in periodontal ligament fibroblasts and decreases the tissue's ability to repair. ${ }^{3}$ The increasing level of these two hormones indicates infection susceptibility in the oral mucosa and lesions appear in the oral cavity. The hormonal changes in pregnant women also affect their behaviours, such as ignoring oral hygiene, which will consequently increases the risk of caries formation and periodontal disease due to the accumulation of plaque and poor oral hygiene. Thus, it is necessary to observe the oral health condition and nutritional status of pregnant women. ${ }^{1,4}$ The purpose of this study was to discover the profile of oral manifestations, oral hygiene, and nutritional status in pregnant women.

\section{METHODS}

This research was a cross-sectional observation performed by observing a phenomenon found at one visit, through the procedures consisted of oral clinical examination, oral hygiene assessment through OHI-S, nutritional measurement using Body Mass Index (BMI), and laboratory examination to check the haemoglobin $(\mathrm{Hb})$ level.

The samples were as many as 108 pregnant women. Data and samples were collected using a consecutive sampling method by the dentist and laboratory analyst, with the inclusion criteria as follows; pregnant women aged 17-43-yearold, visited the Maternal and Child Health Unit of Garuda Community Health Centre in Bandung during August-November 2017, considered as generally healthy, willing to participate in the study, and had not taken any dental cleaning treatment before the survey. The exclusion criteria were having systemic diseases such as tuberculosis and diabetes mellitus, and currently undertaking a long-term antibiotic therapy.

\section{RESULTS}

One hundred eight pregnant women visited the Garuda Community Health Centre during AugustNovember 2017, with characteristics as presented in Table 1 and 2.

Oral manifestations found in the pregnant women were coated tongue, geographic tongue, glossitis, exfoliative cheilitis, and recurrent aphthous stomatitis (RAS). All data showed in Table 2. 


\begin{tabular}{ccccccc}
\hline \multicolumn{7}{c}{ Table 1. OHI-S, BMI, dan Hb mean values in pregnant women } \\
\hline $\begin{array}{c}\text { Number of } \\
\text { respondents }\end{array}$ & $\begin{array}{c}\text { Mean value of } \\
\text { OHI-S }\end{array}$ & OHIS score & $\begin{array}{c}\text { Mean value of } \\
\text { BMl }\end{array}$ & BMl scores & $\begin{array}{c}\text { Mean value of } \\
\mathrm{Hb}(\mathrm{gr} / \mathrm{dl})\end{array}$ & Semester \\
\hline 24 & $1.11 \pm 0.74$ & good & $22.66 \pm 3.92$ & Ideal & 11.77 & $1^{\text {st }}$ \\
31 & $1.19 \pm 1.18$ & good & $25.51 \pm 5.49$ & Overweight & 11.97 & $2^{\text {nd }}$ \\
53 & $1.99 \pm 0.94$ & medium & $26.96 \pm 4.00$ & Overweight & 12 & $3^{\text {rd }}$ \\
\hline
\end{tabular}

Table 2. The oral manifestation in pregnant women

\begin{tabular}{ccc} 
Number & Manifestation & Number of respondents \\
\hline 1 & Coated Tongue & 83 \\
2 & Geographic Tongue & 17 \\
3 & Glossitis & 5 \\
4 & Exfoliative Cheilitis & 4 \\
\hline
\end{tabular}

\section{DISCUSSION}

Some oral manifestations are found more than one in a pregnant woman. The most frequently encountered was coated tongue, as a consequence of food consumption changes resulting in debris retention and pigments in food from a soft diet combined with poor oral hygiene. ${ }^{5-6}$ Glossitis and geographic tongue were found in mild anaemic pregnant women. The aetiological factors, for instance, stress and imbalanced nutrition as the effect of die-tary intake changes, also potentially triggered a geographic tongue. The fissured tongue as a complication of the geographic tongue may also occur. Nutritional deficiency is indeed predisposing the occurrence of RAS. . $^{5-6}$ From the survey conducted also found a relatively small number of oral manifestation related to the systemic condition due to the regular examination performed by the health practitioners. The women are routinely scheduled to check their pregnancy, or having blood examination if necessary, and also given multi-vitamins. All of these treatments are carried out to make sure the mother and the baby are in good and healthy condition.

The observation was performed by grouping the pregnant women into three categories based on the trimesters' stage, which was the first, second, and third trimester. The re-sults showed that oral hygiene status from the first and second trimesters of pregnancy was in a good category, while the third group was categorised as moderate (Table 1), these findings showed that along with increasing gestational age, oral hygiene behaviour also changes as a result of hormonal changes. This result was similar with the previous study conducted by Retnoningrum ${ }^{7}$, which presented that gestational condition can predispose gingivitis, as an effect from an excessive gingival inflammatory response to the dental plaque and hormonal changes during the pregnancy. The condition will become worse in different pregnant women behaviour.

Poor oral hygiene will precede gingivitis and damage the teeth structure, which results in caries. If the condition has started from the early age of the pregnancy, and the mother has poor oral hygiene care, the gingivitis and tooth decay will become more severe along with increasing gestational age. ${ }^{7,8,9}$

The pregnant women examination based on the ratio of height and weight gain showed that the BMI values on the 1st trimester were ideal, and subsequently increasing on the $2^{\text {nd }}$ and $3^{\text {rd }}$ trimesters, and categorised as overweight as shown in Table 1.

According to Guyton', the increase of weight in gravid women consist of two parts, which are embryonal and the mother's tissue. However, in the third trimester, it was dominated by the fetus. The growth of the embryo and the condition of the baby's birth depends on the mother's nutrition. ${ }^{10}$ The mother with sufficient nutrition during the preg-nancy is likely to have a regular pregnancy period and give birth to a healthy baby with an average weight. The weight gain of the subjects in this research was indicating no lack of nutrition. On the other hand, an overweight may 
lead to asphyxia, gestational diabetes, or one the indication for caesarian birth. ${ }^{11}$

The age of the samples was varied from 1743 year old. WHO is recommended the ideal age for conceiving a baby is 20-30 years old. The reason is that in the particular age, the nutritional status in women is at its best. Furthermore, women need more nutrition at a younger age for their growth and the baby. ${ }^{12}$

$\mathrm{Hb}$ level is one of the biochemical indicators to assessed gestational nutritional status. The $\mathrm{Hb}$ level measurements of the current study showed that $\mathrm{Hb}$ level in pregnant women on the first trimester was $11.77 \mathrm{gr} / \mathrm{dl}$ on average; 11.97 $\mathrm{gr} / \mathrm{dl}$ on the second trimester; and $12 \mathrm{gr} / \mathrm{dl}$ on the third trimester (Table 1). These conditions were considered as normal. It means that none of the pregnant women in Garuda Community Health Centre was anaemic. The normal $\mathrm{Hb}$ level needs to be maintained to prevent underweight baby, bleeding in pre and post-birth, and even mortality of the mother and the baby..$^{13}$ Exceeding $\mathrm{Hb}$ level can also increase the risk of the baby developmental disorder. ${ }^{14}$

\section{CONCLUSION}

The most frequently oral manifestation found in pregnant women is coated tongue, and the least is re-current aphthous stomatitis (RAS). Oral hygiene examination showed that in the $1^{\text {st }}$ and $2^{\text {nd }}$ trimester, pregnant women have good oral hygiene, and turns to be moderate on the last trimesters. Meanwhile, the gestational nutritional status in the 2nd and 3rd trimester is considered as bad or under the condition of overweight.

\section{REFERENCES}

1. Rabinerson D. [Ethics in obstetrics and gynecology]. Harefuah. 2011; 150(5): 470-4, 489.

2. Sonbul H, Ashi H, Aljahdali E, Campus G, Lingstrom $P$. The Influence of Pregnancy on Sweet Taste Perception and Plaque Acidogenicity. Matern Child Health J. 2017; 21(5): 1037-1046. DOI: 10.1007/s10995-0162199-2
3. Cekici A, Kantarci A, Hasturk H, Van Dyke TE. Capillary permeability inhibits collagen and non-collagen formation in periodontal ligament fibroblasts and decreases the tissue's ability to repair. Periodontol 2000. 2014; 64(1): 57-80. DOI: $10.1111 / \mathrm{prd} .12002$

4. Yenen Z, Atacag T. Oral care in pregnancy. J Turk Ger Gynecol Assoc. 2019; 20(4): 264-268. DOI: 10.4274/jtgga. galenos.2018.2018.0139

5. Scully C. Handbook of Oral Diseases Diagnosis and Management. $1^{\text {st }}$ ed. London: Martin Dunitz Publishers; 2001.

6. Alikhani $M$, Khalighinejad $N$, Ghalaiani $P$, Khaleghi MA, Askari E, Gorsky M. Immunologic and Psychologic Parameters Associated with Geographic Tongue. Oral Surg Oral Med Oral Pathol Oral Radiol. 2014; 118(1): 68-71. DOI: 10.1016/j.0000.2014.03.007

7. Retnoningrum D. Gingivitis pada ibu hamil sebagai faktor resiko terjadinya bayi berat badan lahir rendah kurang bulan di RS. Kariadi Semarang [minor thesis]. Semarang: Diponegoro University; 2006. p. 1-8.

8. Srivastava A, Gupta KK, Srivastava S, Garg J. Effect of Sex Hormones on the Gingiva in Pregnancy : A Review and Report of Two Cases. J Periodontol Implant Dent. 2011; 3(2): 837.

9. Guyton AC, Hall JE. Buku Ajar Fisiologi Kedokteran. $11^{\text {th }}$ ed. Jakarta: EGC; 2008.

10. Morrison JL, Regnault TRH. Nutrition in Pregnancy: Optimising Maternal Diet and Fetal Adaptations to Altered Nutrient Supply. Nutrients. 2016; 8(6): 342. DOI: $10.3390 /$ nu8060342

11. Stubert J, Reister F, Hartmann S, Janni W. The Risks Associated With Obesity in Pregnancy. Dtsch Arztebl Int. 2018; 115(16): 276-283. DOI: $10.3238 /$ arztebl.2018.0276

12. Mynarska M. Deadline for parenthood: Fertility postponement and age norms in Poland. Eur $\mathrm{J}$ Population. 2010; 26: 351-73. DOI: $10.1007 /$ s10680-009-9194-X

13. Abu-Ouf NM, Jan MM. The impact of maternal iron deficiency and iron deficiency 
anemia on child's health. Saudi Med J. 2015; 36(2): 146-149. DOI: 10.15537/ smj.2015.2.10289
14. Rifda N, Hidayat W, Dewi TS. Hubungan oral hygiene dengan coated tongue pada ibu hamil. Padj J Dent Res; 2(1): 65-70. 